\title{
Coping behavior of women with breast cancer with visible postsurgery deformity
}

\author{
Natal'ja A. Sirota, Bronislav A. Fetisov \\ Moscow State University of Medicine and Dentistry named after A. I. Evdokimov, Moscow, Russia
}

\begin{abstract}
Research was carried out to explore coping strategies in cancer patients. In all, 70 women with breast cancer were studied: 35 of them had visible postsurgery deformity, and 35 did not have visible postsurgery deformity. The purpose of the research was to uncover their preferences for using various strategies and resources to cope with their illness. The results showed that both groups of women had a special set of strategies for coping with stress. The women with visible postsurgery deformity made significantly less use of resources for coping with their illness than did the subgroup of women without visible postsurgery deformity.
\end{abstract}

Keywords: coping strategies, coping resources, breast cancer, postsurgery deformity, stress

Cancer as a diagnosis poses a great threat to both physical and mental health. Lack of knowledge and relative ignorance of state-of-the-art treatment methods lead to the introduction of unreliable, mythic information about cancer. For this reason patients develop a sequence of psychogenic reactions where hope and despair alternate with each other causing now depression or apathy and then anxiety or euphoria depending on personality characteristics (Gnezdilov, 2001). As Chulkova and Moiseyenko (Moiseyenko \& Chulkova, 2009, p. 151) emphasize, "Cancer involves intensive and painful patient feelings associated with danger to life, mutilating surgery, serious long-term treatment, changes in social status and financial status." Breast-cancer surgery not only leaves visible scars but also creates a traumatic situation for individual psychological health. Surgery resulting in total or partial loss of a breast is associated not only with the loss of health, job, and previous status but also with the loss of a symbol of femininity and maternity as well as with the deterioration of sexual life. Studies of the emotional significance of the breast in a woman's life have demonstrated that the breast is inherently the symbol of female pride in sexuality and maternity (Renneker \& Culter, 1952).

For a woman breast cancer is a special illness because it damages one of the most important functional (breastfeeding) and esthetic (female attractiveness) organs needed for a productive life. This illness causes physical and psycholog- 
ical damage: a woman loses her physical health along with her sex appeal and sexuality. Considering the philosophical-psychological aspects of investigations of reproductive function, Zinchenko (Zinchenko ,2003) emphasizes that sexuality influences mental processes in many human activities; therefore disorders in this sphere affect the whole human sphere.

Having an illness, especially cancer, is considered not only a medical problem but also a social and psychological problem because "the illness changes society's attitude to the patient" (Tkhostov, 2002, p. 144). An illness, particularly cancer, entails a change in the integrity of the patient's personality (Nikolayeva, 1987; Tkhstov, 1991). Therefore, it is necessary to have coping behaviors presented in order to provide a patient with qualified medical assistance. Presently, behavioral coping strategies are underrepresented in the Russian literature; however vast experience has been accumulated in the writings of such authors as Kryukova (2005), Nartova-Bochaver (1997), Postylyakova (2004), Sirota \& Fetisov (2012), Sirota \& Moskovchenko (2012), Sirota (1994 / 2012), Yaltonsky (1994 / 2012).

\section{Study design}

\section{Study rationale}

The study investigated psychological markers in women with breast cancer who had undergone the following surgeries:

- women with breast cancer with visible postsurgery deformity (VPD) (Group A) who had undergone

- mastectomy

- extended radical mastectomy

The whole breast was removed in this group of women.

- women with breast cancer without VPD (Group B) who had undergone

- mastectomy with endoprosthesis replacement

- radical resection

- subtotal resection with mammoplasty

In this group of women the breast was either totally removed and replaced by endoprosthesis or partially removed without VPD. VPD.

The purpose of the study was to investigate the coping behavior of women with

\section{Study objectives}

1. To explore the coping strategies of women with VPD.

2. To explore the characteristics of religious coping in women with VPD.

3. To explore the particularities of social-support appreciation, self-attitude, and locus of control in women with VPD.

4. To investigate the particularities of illness interpretation in women with VPD. 
5. To investigate anxiety and depression in women with VPD.

6. To perform a comparative analysis of the study results for women with VPD and women without VPD.

On the basis of the study purpose and objectives, a specific complex of methods was chosen:

1. Stress Coping-Strategy Indicator (SCSI) by Amirkhan (1990) (Russian-language version by V. M. Yaltonsky and N. A. Sirota)

2. Brief RCOPE Scale (Religious Coping Scale) by Pargament (2011) (Russian-language version by N. A. Sirota and B. A. Fetisov)

3. Multidimensional Scale of Perceived Social Support (MSPSS) Questionnaire by Zimmet (1988) (Russian-language version by V. M. Yaltonsky and N. A. Sirota; modified N.A. Sirota and B.A. Fetisov (2012))

4. Self-Attitude Test Questionnaire by Stolin and Pantileyev (1988, pp. 83-93)

5. Self-Control Level Questionnaire by Bazhin, Golynkina, and Etkind (1984)

6. Point-of-Care Testing of the Prevalent Interpretation of Illness in Cancer Patients by A. Büssing, J. Fischer (2009) (Russian-language version by N. A. Sirota, D. V. Moskovchenko, and B. A. Fetisov)

7. Hospital Anxiety and Depression Scale by Zigmond and Snaith (1983)

\section{Sociodemographic data}

The study involved 70 women with a diagnosis of stage I, II breast cancer who had already gone through breast surgery. All the women were hospitalized in the IV Department of Surgery of Moscow Cancer Research Institute of Medical Technologies of Russia named after P. A. Herzen. There were 35 women with VPD and 35 women without VPD. The specific characteristics of the groups are shown in Table 1.

Table 1. Sociodemographic and Clinical Data of Women with VPD (Group A) and Women without VPD (Group B)

\begin{tabular}{lcc}
\hline \multicolumn{1}{r}{ Parameter } & Group A & Group B \\
\hline Number of women & 35 & 35 \\
Age $(\mathrm{Me} \pm \mathrm{SD})$ & $51.71 \pm 7.68$ & $48.6 \pm 8.75$ \\
Stage & I, II & I, II \\
\hline
\end{tabular}

Note. Me - mean; SD - standard deviation.

\section{Study results}

There was no significant difference in coping strategies between the women with VPD and the women without VPD, as assessed by the Stress Coping Strategy Indicator (SCSI) method. Both groups used identical coping strategies. The results obtained with this method are presented in Table 2. 
Table 2. Coping Strategies of Women with VPD (Group A) and Women without VPD (Group B) According to the SCSI Method

\begin{tabular}{lccc}
\hline \multicolumn{1}{c}{ Coping strategies } & $\begin{array}{c}\text { Group A } \\
(\mathrm{Me} \pm \mathrm{SD})\end{array}$ & $\begin{array}{c}\text { Group B } \\
(\mathrm{Me} \pm \mathrm{SD})\end{array}$ & $\begin{array}{c}\text { Significant difference on } \\
\text { the Mann-Whitney "U” test }\end{array}$ \\
\hline Problem solving & $29.8 \pm 3.13$ & $29.91 \pm 3.28$ & - \\
Seeking of social support & $24.77 \pm 5.18$ & $24.88 \pm 5.51$ & - \\
Avoidance & $19.97 \pm 2.97$ & $19.14 \pm 3.55$ & - \\
\hline
\end{tabular}

Note. $\mathrm{Me}$ - mean; SD — standard deviation.

The women with VPD actively used religious coping. However, compared with the group of women without VPD, they significantly more often adopted negative religious coping (Table 3).

Table 3. Religious Coping Strategies of Women with VPD (Group A) and Women without VPD (Group B) on the Brief RCOPE Scale.

\begin{tabular}{lccc}
\hline Coping strategies & $\begin{array}{c}\text { Group A } \\
(\mathrm{Me} \pm \text { SD) }\end{array}$ & $\begin{array}{c}\text { Group B } \\
(\mathrm{Me} \pm \text { SD) }\end{array}$ & $\begin{array}{c}\text { Significant difference on } \\
\text { the Mann-Whitney “U” test }\end{array}$ \\
\hline Positive religious coping & $13.25 \pm 6.12$ & $12 \pm 6.27$ & - \\
Negative religious coping & $6.37 \pm 5.26$ & $3.6 \pm 3.92$ & $\mathrm{p}<0.001$ \\
\hline
\end{tabular}

Note. $\mathrm{Me}$ - mean; SD - standard deviation.

The women with VPD had signs of spiritual tension, conflict, and struggle with God and others. Negative religious coping strategies were manifested in negative reappraisals of God's powers (e.g., feeling abandoned or punished by God), demonic reappraisals (i.e., feeling the devil is involved in the stressor), spiritual questioning and doubting, and religious discontent.

The level of appreciation for social support was high in both groups. The women increasingly appreciated support from family. Results obtained with this scale are presented in the Table 4.

Table 4. Scores of Women with VPD (Group A) and Women without VPD (Group B) on the MSPSS

\begin{tabular}{lccc}
\hline \multicolumn{1}{c}{ Scores } & $\begin{array}{c}\text { Group } \\
\boldsymbol{A}(\mathrm{Me} \pm \mathrm{SD})\end{array}$ & $\begin{array}{c}\text { Group } \\
\boldsymbol{B}(\mathrm{Me} \pm \mathrm{SD})\end{array}$ & $\begin{array}{c}\text { Significant difference on } \\
\text { the Mann-Whitney “U” test }\end{array}$ \\
\hline Family & $3.62 \pm 0.73$ & $3.28 \pm 0.98$ & - \\
Friends & $2.31 \pm 1.64$ & $2.25 \pm 1.7$ & - \\
Significant others & $3.08 \pm 1.22$ & $2.68 \pm 1.51$ & - \\
Doctor & $2.91 \pm 1.31$ & $2.88 \pm 1.4$ & - \\
Total score & $11.91 \pm 3.68$ & $11.05 \pm 4.41$ & - \\
\hline
\end{tabular}

Note. Me - mean; SD — standard deviation. 
Special attention should be paid to the results of the Self-Attitude Test Questionnaire. The women with VPD in general scored lower than the women without VPD with the exception of their scores on the self-blame coping strategy. This difference may be a consequence of the specific nature of the surgery that caused breast deprivation and cosmetic defect in the women with VPD. The results are shown in Table 5.

Table 5. Self-Attitude Test Questionnaire Scores of Women with VPD (Group A) and Women without VPD (Group B)

\begin{tabular}{lccc}
\hline \multicolumn{1}{c}{ Score } & $\begin{array}{c}\text { Group A } \\
(\text { Me } \pm \text { SD })\end{array}$ & $\begin{array}{c}\text { Group B } \\
(\text { Me } \pm \text { SD })\end{array}$ & $\begin{array}{c}\text { Significant difference on } \\
\text { the Mann-Whitney “U” test }\end{array}$ \\
\hline $\begin{array}{l}\text { S Score - integrated sense } \\
\text { of pros and cons of own self }\end{array}$ & $76.85 \pm 19.09$ & $86.72 \pm 11.78$ & $\mathrm{p}<0.01$ \\
$\begin{array}{l}\text { Score I - self-esteem } \\
\text { Score II - self-sufficiency }\end{array}$ & $61 \pm 26.04$ & $75.03 \pm 24.38$ & $\mathrm{p}<0.05$ \\
$\begin{array}{l}\text { Score III - attitudes } \\
\text { expected from others }\end{array}$ & $56.44 \pm 21.92$ & $79.72 \pm 17.15$ & $\mathrm{p}<0.01$ \\
Score IV - self-concern & $67.38 \pm 27.58$ & $60.38 \pm 24.12$ & - \\
$\begin{array}{l}\text { Score 1 - self-confidence } \\
\text { Score 2 - respect from }\end{array}$ & $54.25 \pm 25.12$ & $66.14 \pm 27.62$ & $\mathrm{p}<0.05$ \\
others & $60.76 \pm 23.98$ & $61.66 \pm 23.57$ & $\mathrm{p}<0.05$ \\
Score 3 - self-acceptance & $74.1 \pm 25.62$ & $78.72 \pm 22.04$ & - \\
$\begin{array}{l}\text { Score 4 - self-control, } \\
\text { self-order }\end{array}$ & $62.73 \pm 20.33$ & $67.35 \pm 18.31$ & - \\
Score 5 - self-blame & $51.38 \pm 31.38$ & $33.85 \pm 25.62$ & - \\
Score 6 - self-concern & $71.42 \pm 24.88$ & $76.8 \pm 21.29$ & $\mathrm{p}<0.01$ \\
Score 7 - self-concept & $60.45 \pm 24.97$ & $71.91 \pm 21.71$ & $\mathrm{p}<0.05$ \\
\hline
\end{tabular}

Note. Me - mean; SD — standard deviation.

Compared with the women without VPD, the women with VPD were characterized as follows: they were not satisfied with their capabilities and felt weak. They doubted their ability to be inspired, respected, sympathized with, comprehended, and accepted by others. They were dependent on externals, had decreased self-regulation, and wished to change themselves. These patients were doubtful of the value of their own personality and tried to be congruent with their self-ideal. They were ready to blame themselves for all their faults and failures. They had a low self-concept, depreciated their spiritual self, and had low interest in their own inner world (Bodalev \& Stolin, 1987, pp. 264-267; Pantileyev, 1999)

All the scores of the women with VPD on the Self-Control Level Questionnaire were not higher than an average of 5.5. This result points out their external orientation. Data are presented in Table 6. 
Table 6. The Self-Control Level Questionnaire Scores of Women with VPD (Group A) and Women without VPD (Group B)

\begin{tabular}{lccc}
\hline \multicolumn{1}{c}{ Scores } & $\begin{array}{c}\text { Group A } \\
(\mathrm{Me} \pm \text { SD) }\end{array}$ & $\begin{array}{c}\text { Group B } \\
(\mathrm{Me} \pm \text { SD) }\end{array}$ & $\begin{array}{c}\text { Significant difference on } \\
\text { the Mann-Whitney “U” test }\end{array}$ \\
\hline $\begin{array}{l}\text { General internality score } \\
\begin{array}{l}\text { Achievements internality } \\
\text { score }\end{array}\end{array}$ & $3.65 \pm 1.21$ & $4.37 \pm 1.18$ & $\mathrm{p}<0.05$ \\
$\begin{array}{l}\text { Failures internality score } \\
\begin{array}{l}\text { Family-relations internality } \\
\text { score }\end{array}\end{array}$ & $3.68 \pm 1.64$ & $5.68 \pm 2.36$ & - \\
$\begin{array}{l}\text { Working-relations interna- } \\
\text { lity score }\end{array}$ & $4.48 \pm 1.56$ & $4.31 \pm 1.96$ & - \\
$\begin{array}{l}\text { Interpersonal-relations } \\
\text { internality score }\end{array}$ & $5.08 \pm 1.44$ & $3.71 \pm 1.85$ & - \\
$\begin{array}{l}\text { Health and illness interna- } \\
\text { lity score }\end{array}$ & $4.57 \pm 2.07$ & $6.85 \pm 1.95$ & $\mathrm{p}<0.001$ \\
\hline
\end{tabular}

Note. Me - mean; SD - standard deviation.

Compared with the women without VPD, the women with VPD noted a connection between their actions and significant events less often. They believed that they were not able to control the progression of events and supposed that most events were dependent on chance or the actions of others (Bazhin, Golynkina, \& Etkind, 1984).

The women's interpretation of their illness was assessed by the Point-of-Care Testing of the Prevalent Interpretation of Illness in Cancer Patients methodology. The results are showed in Table 7.

Table 7. Point-of-Care Testing of the Prevalent Interpretation of Illness in Cancer Patients Scores of Women with VPD (Group A) and Women without VPD (Group B)

\begin{tabular}{|c|c|c|c|}
\hline Score & $\begin{array}{c}\text { Group } \\
A(\mathrm{Me} \pm \mathrm{SD})\end{array}$ & $\begin{array}{c}\text { Group } \\
B(\mathrm{Me} \pm \mathrm{SD})\end{array}$ & $\begin{array}{l}\text { Significant difference on } \\
\text { the Mann-Whitney " } U \text { " test }\end{array}$ \\
\hline Feeling of guilt & $3.6 \pm 2.69$ & $3.2 \pm 1.92$ & - \\
\hline Fatalistic interpretations & $5.77 \pm 2.83$ & $4.34 \pm 2.23$ & $\mathrm{p}<0.01$ \\
\hline $\begin{array}{l}\text { Interpretation of illness } \\
\text { as a strategy }\end{array}$ & $3.57 \pm 2.13$ & $2.8 \pm 1.53$ & - \\
\hline $\begin{array}{l}\text { Positive interpretation of } \\
\text { illness }\end{array}$ & $4.88 \pm 3.16$ & $3.91 \pm 3.19$ & - \\
\hline
\end{tabular}

Note. Me - mean; SD - standard deviation.

Compared with the women without VPD, women with VPD statistically more often interpreted their illness negatively; they considered their illness as divine retribution, requital, or justifiable punishment. Such an attitude supposes a pseudoactive position when combatting cancer: a woman may announce plans for recovery to medical professionals but may in fact exhibit passivity in performing the tasks of treatment. 
The women with VPD had significantly higher anxiety scores (located in the area of subclinical severe anxiety) than the women without VPD. The mean scores for depression are also located in the area of subclinical severe anxiety. The results are shown in Table 8.

Table 8. Hospital Anxiety and Depression Scale Scores of Women with VPD (Group A) and Women without VPD (Group B).

\begin{tabular}{lccc}
\hline \multicolumn{1}{c}{ Score } & $\begin{array}{c}\text { Group } \\
\boldsymbol{A}(\mathrm{Me} \pm \mathrm{SD})\end{array}$ & $\begin{array}{c}\text { Group } \\
\boldsymbol{B}(\mathrm{Me} \pm \mathrm{SD})\end{array}$ & $\begin{array}{c}\text { Significant difference on the } \\
\text { Mann-Whitney “U” test }\end{array}$ \\
\hline Score anxiety & $10.22 \pm 3.8$ & $6.17 \pm 3.55$ & $\mathrm{p}<0.01$ \\
Score depression & $8.05 \pm 3.07$ & $5 \pm 3.38$ & - \\
\hline
\end{tabular}

Note. $\mathrm{Me}$ - mean; SD - standard deviation.

The results demonstrate that women with VPD experience severe anxiety and may develop depression. We assume these conditions have two bases:

- for the breast cancer itself, the progression of the illness and the receiving of medical care

- for the absence of the breast, complications in women's readjustment and interaction with others because of their "new look"

\section{Conclusions}

1. The results obtained in the two groups of women show they moderately adopted strategies to cope with their illness using mostly "problem solving" and "social support seeking."

2. The strategies often used by both groups of women to cope with their illness were based in religious faith. The group of women with oncology pathology tended to adopt negative religious coping.

3. Both groups appreciated social support. Mostly, they appreciated family and other special support people.

4. The group of women with VPD demonstrated external locus of control.

5. The women with VPD assigned a fatalistic meaning to their illness.

6. The women with VPD had significantly higher anxiety scores in reference to clinically apparent anxiety and clinically apparent depression.

\section{References}

Amirkhan J. H. (1990). A Factor analytically drived measure of coping: The coping strategy indicator. Journal of Personality and Social Psychology, 59(5), 1066-1074.

Bazhin, E. F., Golynkina, E. A., \& Etkind, A. M. (1984). Metod issledovaniya urovnya sybyektivhogo kontrolya [Method of assessment of the level of self-control]. Psikhologicheskiy zhurnal [Psychological journal], 5(3), 152-162. 
Bodalev, A. A., \& Stolin, V. V. (1987). Obshchaya psikhodiagnostika [General psychodiagnostics], 264-267. Moscow: Printing House of Moscow State University.

Büssing A, Fischer J. (2009). Interpretation of illness in cancer survivors is associated with health-related variables and adaptive coping styles. BMC Women's Health, 9(2), 1-11.

Chulkova, V. A., \& Moiseyenko, V. M. (2009). Psikhologicheskiye problemy v onkologiye. [Psychological issues in oncology]. Zhurnal Prakticheskaya onkologiya [Journal Practical Oncology], 10(3), 151-157.

Gnezdilov, A.V. (2001). Psikhicheskiye izmeneniya u onkologicheskikh bolnykh [Psychological changes in cancer patients]. Zhurnal Prakticheskaya onkologiya [Journal Practical oncology], 5(1), 5-13.

Kryukova, T. L. (2008). Psikhologiya sovladayushchego povedeniya v raznye periody zhizni [Psychology of coping behavior in different periods of life]. (PhD thesis). Kostroma.

Nartova-Bochaver, S. K. (1997). «Coping Behavior» v sisteme ponyatiy psikhologii lichnosti [«Coping Behavior» to the system of concepts of personality psychology]. Psikhologicheskiy zhurnal [Psychological journal], 18(5), 20-30.

Nikolayeva, V.V. (1987). Vliyaniye khronicheskoy bolezni na psikhiku [Impact of chronic disease on the psyche]. Moscow: Moscow State University.

Pantileyev, S. R. (1999). Praktikum po psikhodiagnostike: rukovodstvo po interpretatsii [Practical work to psychodiagnostics: manual on the interpretation], 82-94. Moscow: MSU.

Pargament, K. I. (2011). The Brief RCOPE: Current psychometric status of a short measure of religious coping. Religions, 2, 58.

Postylyakova, Yu. V. (2004). Psikhologicheskaya otsenka resyrsov sovladaniya so stressom v professionalnykh gruppakh [Psychological evaluation of coping resources in occupational groups]. (PhD Thesis). Moscow.

Renneker, R., \& Culter, M. (1952). Psychological problems of adjustment to cancer of the breast. Journal of the American Medical Association, 148(10), 833-839. doi: 10.1001/ jama.1952.02930100051011

Sirota, N. A. (1994). Koping - povedeniye v podrostkovom vozraste [Coping behavior in teenage age]. (Thesis). St. Petersburg.

Sirota, N. A, Moskovchenko, D. V. (2012) Sovladayushcheye povedeniye i vospriyatiye sotsial'noy podderzhki u zhenshchin, stradayushchikh rakom yaichnikov i rakom molochnoy zhelezy [Coping behavior and perception of social support in women with ovarian cancer and breast cancer]. Sovremennyye problemy gumanitarnykh $i$ yestestvennykh nauk [Modern problems Humanities and Sciences]. Moscow: Publishing House "Spetskniga".

Sirota, N. A. \& Fetisov, B. A. (2012). Koping - povedeniye zhenshchin bol'nykh rakom molochnoy zhelezy [Coping behavior women with breast canser]. Moscow: IPRAN.

Sirota, N. A. \& Fetisov, B. A. (2012). Psikhologicheskiye aspekty onkologicheskogo zabolevaniya na primere raka molochnoy zhelezi [Psychological aspects of cancer disease: of breast cancer an example]. Voprosy. Gipotezy. Otvety: nauka XXI veka [Questions. Hypotheses. Answers: science of the XXI century], 1, 5. Krasnodar.

Sirota, N. A. \& Yaltonsky, V. M. (1994). Koping - povedeniye i psikhoprofilaktika psikhosotsial'nykh rasstroystv u podrostkov [Coping behavior and psychoprophylaxis psychosocial distress at teenagers]. Obozreniye psikhiatricheskoy i meditsinskoy psikhologii [Review of mental health and medical psychology], 1, 63-64. St. Petersburg.

Stolin, V. V., \& Pantileyev, S. R. (1988). Oprosnik samootnoshenija [Self-Attitude Test Questionnaire]. Praktikum po psihodiagnostike: Psihodiagnosticheskie materialy [Case Study on Psychodiagnostics: Psychodiagnostical Materials]. Moscow: Moscow State University. 
Tkhostov, A. Sh. (2002). Psikhologiya telesnosti [Psychology physicality]. Moscow: Sense.

Tkhostov, A. Sh. (1991). Interpretatsiya v structure vnutrenney kartiny bolezni [Interpretation in the Structure of the Inner Pattern of Illness]. Dissertatsiya doktora psikhologicheskikh nauk [Dissertation of the doctor of psychological sciences]. Moscow.

Yaltonsky, V. M. (1995). Koping - povedeniye zdorobykh I bol'nykh narkomanieey [Coping behavior of healthy and drug addicts]. (Thesis). St. Petersburg.

Zigmond, A. S., \& Snaith, R. P. (1983). The Hospital Anxiety and Depression scale. Acta Psychiatr. Scand, 67, 361-370.

Zinchenko, Yu. P. (2003). Filosofsko-psikhologicheskiye aspekty izucheniya reproduktivnoy funktsii [Philosophical and psychological aspects of the study of reproductive function]. Vestnik Moskovskogo universiteta. Serija 7. Filosofija [The Moscow University Herald. Series 7. Philosophy], 7(5), 53-61. 